\title{
In vitro culture of bovine preantral follicles: a review
}

\author{
Valdevane R Araújo ${ }^{1,2}$, Melba O Gastal ${ }^{1}$, José R Figueiredo ${ }^{2}$ and Eduardo L Gastal ${ }^{1 *}$
}

\begin{abstract}
Preantral follicles are the majority of the ovarian follicle population and their use as a source of homogeneous oocytes for bovine reproductive biotechnologies could result in a substantial advance in this field. However, while in other species embryos and offspring have been produced, in bovine species the results have been limited to the follicular activation of small (primordial) preantral follicles and formation of early antral follicles from large (secondary) preantral follicles after in vitro culture. Therefore, this review will highlight the basic aspects of bovine folliculogenesis by focusing on preantral follicles, the methods of harvesting preantral follicles, the main results from in vitro follicular culture during the last 20 years, and the potential candidate substances (basic supplements, growth factors, and hormones) for improving the efficiency of in vitro follicle growth.
\end{abstract}

Keywords: Cow, Folliculogenesis, Oocyte, Ovarian follicles

\section{Background}

The mammalian ovary is responsible for the development, maturation, and release of mature oocytes for fertilization, as well as for the synthesis and secretion of hormones that are essential for follicular development, menstrual/estrous cyclicity, and maintenance of the reproductive tract and its function. In cattle, from mid-pregnancy to reproductive senescence many follicles are activated to enter the growth phase, which is characterized by both proliferation of the granulosa cells and an increase in the oocyte size [1]. However, most of these follicles gradually become atretic during in vivo growth phase; this fact has stimulated great interest in the development of a culture system that might be able to maintain follicular growth and avoid this loss of follicles.

Considering that primordial follicles constitute the supreme starting material for in vitro culture due to their large number when compared with mature follicles [2], it would be of remarkable help to possess a renewable source of primordial follicles from high-yielding animals for culture in order to maximize offspring from these animals [3]. Moreover, elucidation of the poorly understood mechanisms of primordial follicle activation would

\footnotetext{
* Correspondence: egastal@siu.edu

${ }^{1}$ Department of Animal Science, Food and Nutrition, Southern Illinois University, 1205 Lincoln Drive, MC 4417, Carbondale, IL 62901, USA Full list of author information is available at the end of the article
}

constitute an important leap forward in the understanding of follicular dynamics [4].

Preantral follicles for research are usually obtained from ovaries from slaughterhouses or through laparotomy or ovarian biopsies. Studies using ovarian biopsy have shown minimum or no disturbance to ovarian function in several species, including cattle [3-5], horses [6-8], and humans $[2,9]$. This technique will be of great value for experimental or diagnostic purposes. Profound similarities in the dynamics of follicle development exist between the menstrual cycle in women and the estrous cycle in cattle and horses $[10,11]$. In this regard, research using animal models for studying human ovarian function is important to provide a hypothetical basis for further studies in women, which will ultimately lead to the development of safer and more efficacious infertility and contraceptive therapies [12]. Therefore, if preantral follicles could be efficiently isolated from ovaries, a large potential source of oocytes (genetic material) could be obtained to reach meiotic competence in vitro. Moreover, immature oocytes from preantral follicles could be used in other assisted reproductive technologies, such as in vitro maturation and embryo production, transgenesis, and conservation of endangered species.

An in vitro follicle growth system that allows complete growth of oocytes from preantral or early antral follicles has been studied. However, besides the differences among species, in vitro follicle growth success depends on initial 
oocyte size, as well as follicle categories used. In regard to large animals, the production of embryos from buffalo [13], sheep [14,15], goats [16], and monkeys [17] has been obtained only from large advanced secondary follicles. However, in mice, embryos and live offspring have been produced using developmentally competent oocytes obtained after growth entirely in vitro starting with primordial follicles [18,19]. In bovine species the best results have been the antrum cavity formation (tertiary follicles) after in vitro culture of advanced secondary follicles [20].

Ovarian follicular development and oocyte growth depend on a bidirectional communication between oocytes and somatic cells. Oocytes have an essential role in controlling the proliferation and differentiation of granulosa cells during follicular development [21]. The ability to sustain preantral follicle growth in vitro to support the acquisition of oocyte competence could represent a breakthrough in the reproduction field since this source of oocytes could be beneficial for assisted reproductive technologies. Additionally, research aiming at further understanding of somatic cell-oocyte interactions in species with prolonged follicular growth, such as bovines [22], would be of great significance for human reproduction. Therefore, in vitro culture systems have to allow for these conditions and properly maintain cell interactions during follicle development.

This review aims to describe and discuss the advancements in and current status of the emerging research with bovine preantral follicles. Firstly, we summarize current knowledge of achievements in the development of in vitro systems for culture of bovine preantral follicles. Secondly, we address the methods of harvesting preantral follicles, the culture media, and the systems used. Finally, we describe the most common growth factors and hormones utilized to culture bovine preantral follicles.

\section{Review}

\section{Basic aspects of early bovine folliculogenesis}

Development of bovine oocytes and follicles begins in the fetal phase [23] and takes around 6 months to be completed [24]. The follicle development is comprised of two distinct and consecutive phases (Figure 1): the first phase, characterized by the formation and beginning of growth of primordial follicles, and the second phase, in which the growth of primary and secondary follicles occurs as granulosa cells transform from a flattened to a cuboidal shape and proliferate, while the oocyte experiences a rapid increase in size. It has been reported that the critical point of follicle growth is when the follicle has about 40 granulosa cells and the oocyte undergoes the first significant change in diameter [25].

\section{Formation and initiation of primordial follicle growth}

Primordial germ cells proliferate by mitosis to form primary oocytes with the first meiotic prophase starting between days 75 and 80 of pregnancy in cattle [26]. The formation of primordial follicles occurs at the pachytene stage of meiosis, between days 91 and 144 of pregnancy [27] and then arrest at the diplotene stage [27,28]. In primordial follicles the oocyte is surrounded by a single layer of six pre-granulosa (flattened) cells, which is in turn surrounded by a basal membrane; these are the first generation of follicle cells [25] and are derived from the celomic epithelium. From day 170 onward, the ovigerous cords of primordial germ cells are absent and there are only primordial follicles present [26]. After the

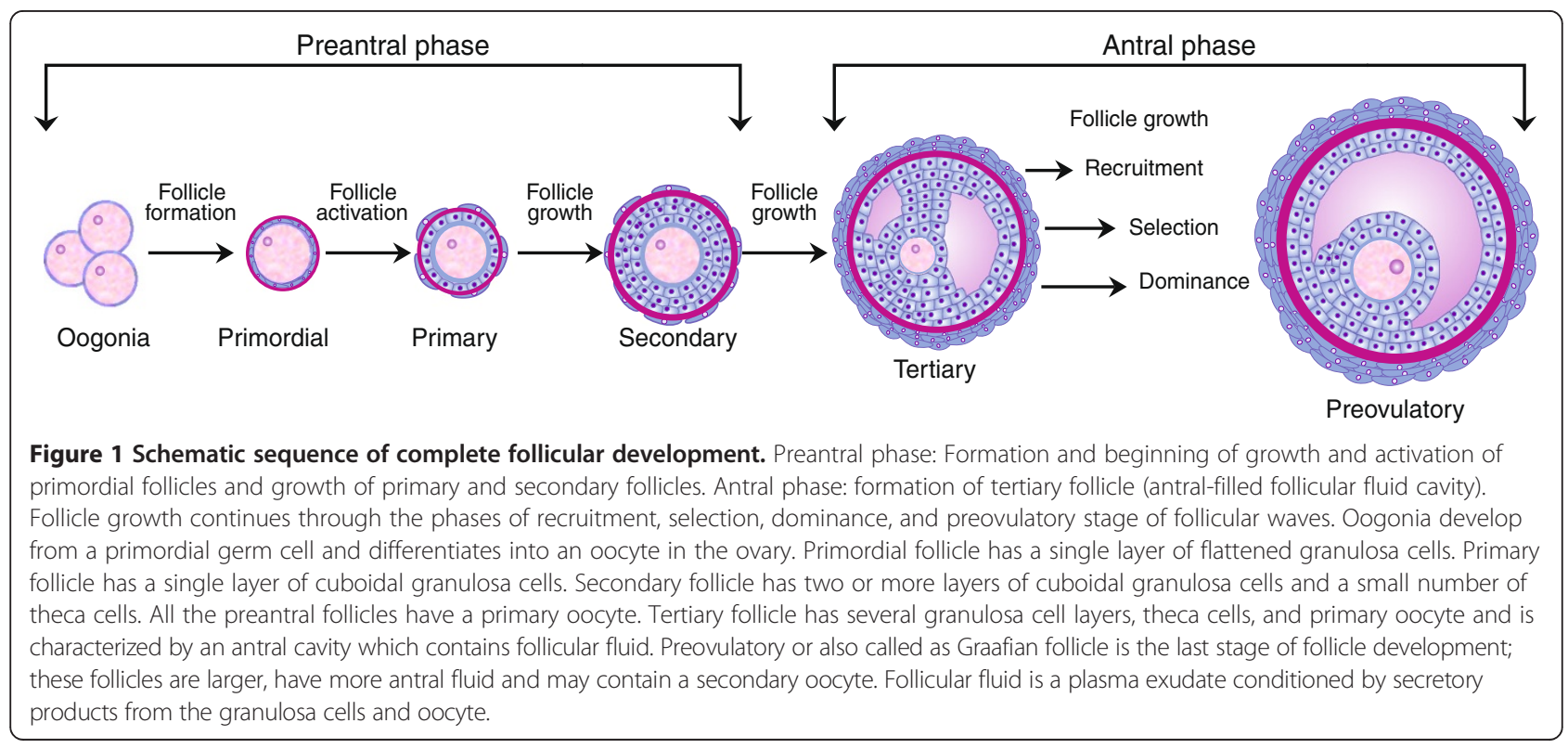


formation of primordial follicles, the pre-granulosa cells stop multiplying and remain in the resting phase until they are stimulated to grow [26]. In bovine species, primordial follicles have a mean diameter of $35.2 \mu \mathrm{m}$ and oocyte growth is initiated only during the fourth generation of follicle cells, compared with the second or third generation in rodents and humans, respectively [25].

During the initiation of follicular growth, in a phase known as primordial follicular activation, some primordial follicles leave the reserve pool of quiescent follicles to enter the growing pool (transitional, primary, secondary, tertiary, and preovulatory stage [23]. The activation of primordial follicles is a nonreversible process; therefore, it is important in regulating the size of the resting primordial follicle pool, which will affect the reproductive lifespan and fertility [27]. Follicular activation is characterized by the morphological modifications of granulosa cells from flattened to cuboidal, as well as the resumption of cell proliferation [29] and the initiation of oocyte growth. However, the factors and mechanisms responsible for the control of early folliculogenesis are still poorly known and represent one of the major questions related to ovarian biology.

\section{Growth of primary and secondary follicles}

After activation, bovine primordial follicles gradually acquire cuboidal granulosa cells and become transitional and primary follicles, the latter with one complete layer of 11-40 cuboidal granulosa cells around the oocyte observed in the largest cross section of the follicle [25,30]. Secondary follicles are characterized by the addition of a second complete layer of granulosa cells, the initial deposition of zona pellucida (ZP) material, formation of cortical granules within the oocyte cytoplasm [31], the beginning of theca cell layer formation [25], mRNA synthesis in the oocyte [22], and gonadotropin responsiveness [32].

Primary and secondary follicles appear in the bovine fetal ovary around days 140 and 210 [23], and have a mean diameter of $46.1 \mu \mathrm{m}$ [30] and $81.0 \mu \mathrm{m}$ (early secondary follicles; [25]), respectively. Unlike in primordial follicles, at these follicular stages the ZP begins to form, surrounding the oocyte [31,33]. Braw-Tal and Yossefi [25] verified that the ZP first appeared in early secondary follicles (range, 81-130 $\mu \mathrm{m}$ in diameter), but formed a complete ring around the oocyte during the late secondary follicle stage (range, 131-250 $\mu \mathrm{m}$ in diameter).

The growth of preantral follicles after the primary stage also depends on important events that include the expression of growth and differentiation factors such as vascular endothelial growth factor (VEGF) and growth and differentiation factor-9 (GDF-9). VEGF, in particular, has been considered as a stimulator of bovine follicular development in vitro because it provides support for the transition from the primary to the secondary follicle stage [34].
During growth of secondary follicles an organization of the granulosa cells occurs in several layers and an antral cavity filled with follicular fluid is formed among these cells [31]. From this stage onwards, the follicles are called tertiary or early antral follicles and have been observed during the bovine fetal phase at days 210 [35] or 230-250 [23] of gestation. The transition from secondary to tertiary stage includes the development of the internal and external theca cell layers and the beginning of cumulus cell formation [31] in follicles around $120 \mu \mathrm{m}$ in diameter [24].

Although antral cavities are usually established when the follicles reach at least $200 \mu \mathrm{m}$ in diameter [24,36], as we mentioned previously, large secondary follicles (greater than $190 \mu \mathrm{m}$ in diameter) have been mechanically isolated from bovine ovaries [37-40], as well as from the ovaries of other species such as goats $[16,41,42]$ and sheep $[14,15]$.

\section{Harvesting bovine preantral follicles \\ Mechanical isolation using tissue chopper or microdissection}

The first studies using mechanical isolation techniques were developed during the early 1990s and represented major advances in the isolation of morphologically normal preantral follicles. Early preantral follicles were mechanically isolated using a machine called a tissue chopper [43], a homogenizer [44], or a cell dissociation sieve $[45,46]$. Furthermore, isolation of later stage preantral follicles via microdissection was reported using insulin needles [47].

Bovine preantral follicles have been successfully isolated utilizing tissue chopper and microdissection. Both follicular isolation methods have shown no detrimental effect on the tridimensional structure of the small follicles because they did not damage the basal membrane ([43,48]; Figure 2A). The preservation of the follicular basal membrane may prevent the spreading of granulosa cells during in vitro culture [48], preserving follicular morphology by maintaining follicular adhesion to extracellular compounds. Additionally, the basement membrane contains proteoheparansulfate [49], which binds to a variety of growth factors [50]. Therefore, the presence of a basement membrane around the follicles might optimize the effects of growth factors and hormones added to the culture medium [51].

The number of follicles isolated by tissue chopper differs according to the species [52] and even among breeds. In goats and sheep, the best results were obtained with the intervals of 75 and $87.5 \mu \mathrm{m}$, respectively $[53,54]$. The best interval for sectioning ovarian tissue varies from $50 \mu \mathrm{m}$ for European cattle (Bos Taurus; [43] and $125 \mu \mathrm{m}$ for Zebu cattle (Bos Indicus; [52]. These differences regarding the cut interval most suitable to isolate preantral follicles may be explained by differences 


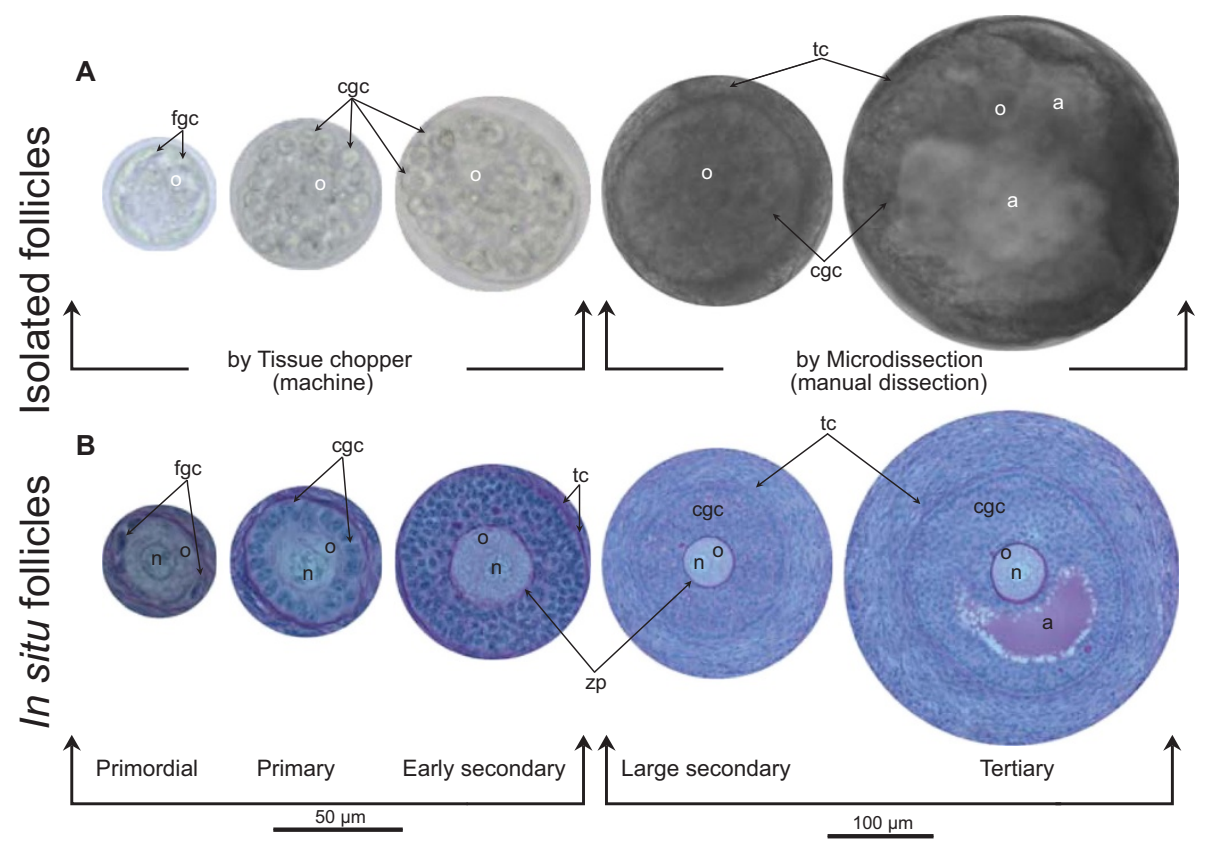

Figure 2 Isolated follicles by tissue chopper and microdissection, and in situ follicles. Isolated follicles (A) by tissue chopper and microdissection, and (B) in situ follicles stained with PAS-hematoxylin. o: oocyte; n: oocyte nucleus; fgc: flattened granulosa cells; cgc: cuboidal granulosa cells; tc: theca cells; zp: zona pellucida. A large secondary follicle and an antral follicle grown in vitro and isolated by microdissection are shown (A).

in quantity of ovarian tissue and variation in its composition, as in corpora lutea and corpora albicans [43]. Follicles embedded in a more fibrous stroma can be more difficult to isolate and smaller cut intervals would be necessary [52].

The microdissection method has been used to isolate large bovine follicles using fine needles under stereomicroscopy. This method maintains the theca cell layers, which ensures follicle quality $[55,56]$. In general, the presence of theca cells is a crucial condition for normal follicular growth, preservation of estrogen production [57], maintenance of follicular health, and remodeling of the basement membrane [58]. Therefore, maintaining communication among the oocyte, the surrounding somatic cells, and the extracellular matrix is vital to the achievement of normal folliculogenesis, and to sustain follicular growth and viability [58]. This technique allows the isolation of several morphologically normal and intact follicles from ovarian tissue. Large bovine preantral follicles have been successfully isolated and cultured in vitro until antrum formation after short- $[22,58]$ and long-term [20,37-39,59] culture.

\section{Enzymatic isolation}

The fibrous nature of the ovaries of most domestic species complicates follicular isolation [60]. Therefore, some studies have been conducted using different types of enzymes to recover preantral follicles in different species.
Collagenase (from Clostridium histolyticum) has been used to isolate numerous preantral follicles from murine [61], swine [62], and bovine [43] ovaries. In addition, an enzymatic method using deoxyribonuclease (DNAse) has been developed to isolate human follicles [63]. However, this latter process requires a lengthy cooling time and consequently reduces the viability of the follicles by causing damage to cell membranes.

The degree of enzymatic damage depends on the duration of treatment, the concentration of the enzyme(s), and the type of tissue [43,64]. Morphologically normal follicles have been isolated from bovine ovaries using a combination of collagenase and DNAse treatment [65]. However, it was reported that although the oocytes from freshly isolated preantral follicles appeared healthy under an inverted microscope, histological examinations revealed that the enzymatic process could have damaged the oocytes, especially in smaller preantral follicles.

\section{Ovarian biopsy in vivo}

A new method for the repeated collection of ovarian biopsies from living donors through transvaginal, ultrasoundguided puncture of the ovary has been successfully developed and tested in cows [3], women [66], and recently in mares [6-8]. This procedure can be seen as a modified version of a commercial ovum pick-up (OPU) technique. Using ovarian biopsies, Aerts et al. [3] had an 
average success rate of $68 \%$ for recovering ovarian fragments. Although rather small, these fragments were suitable for both histological (Figure 2B) and immunohistochemical evaluation and revealed the presence of morphologically normal primordial and growing preantral follicles. In addition, in a later study, the restoration of ovarian tissue morphology (using light microscopy) and the preservation of follicle viability (using fluorescence microscopy) in the majority of preantral follicles after multiple ovarian biopsy sessions was reported [4].

\section{In vitro culture systems for bovine preantral follicles}

For bovine and other farm domestic species, the development of culture systems capable of supporting the growth of immature follicles to a stage where they could be matured and the oocyte fertilized would ensure a large supply of oocytes for manipulation. These oocytes could potentially be used to shorten the generation interval of selected animals and, consequently, to increase the number of offspring born per animal. Development of a successful culture system for preantral follicles with immature oocytes is dependent upon efficient procedures to recover the follicles from the ovary and culture them as well.

Basically, there are two ways to culture bovine preantral follicles: 1) enclosed in ovarian tissue fragments (slices or strips), also called "in situ"; or 2) using isolated follicles. Isolated follicles have been cultured either in a two-dimensional (2D) system (Figure 3A) - i.e. the follicle is placed on the surface, which may be a plastic or extracellular matrix (e.g., collagen gel, matrigel, etc) - or in a three-dimensional (3D) system (Figure 3B), in which the follicles are cultured within an extracellular matrix.

Currently, the major use of isolated follicles for culture is to support the growth and development of immature oocytes and allow the understanding of the mechanisms involved in oocyte development, granulosa cell differentiation, and regulation of autocrine/paracrine factors that control early stages of folliculogenesis [67].

\section{In vitro culture of preantral follicles enclosed in ovarian tissue (in situ)}

In the in situ culture system, follicles are cultured with the surrounding ovarian tissue, including the stromal cells. This culture system allows the interaction between the follicles and their adjacent cells, such as stromal/theca cells and granulosa cells, which may influence their growth [68]. This is a very practical method and prevents prolonged exposure of the cells to the external environment.

The spontaneous activation of primordial follicles has been known to occur in vitro using the in situ culture system in several species, including mice $[18,69]$, cattle ([25,70-74]; Table 1), horses [7], goats [75,76], and primates $[77,78]$. The majority of the bovine primordial follicles cultured in situ may activate within 2 days of culture $[25,27,70]$ and reach the secondary stage in 6 [79], 10 $[27,34,80]$, or 22 days [74].

Despite the fact that in vitro culture of ovarian tissue is able to develop primordial follicles until primary and secondary stages $[27,34,74,80]$, this technique has not been very effective for follicle maturation. A two-step culture system for bovine [79] and human [81] preantral follicles has been tested recently. The aim of this system was to determine whether in situ-grown bovine and human follicles could be isolated at the secondary stage and cultured to late preantral/early antral stages. However, in both species, only a few antral follicles were obtained after 4 [81] or 15 days [79] of culture of secondary follicles.
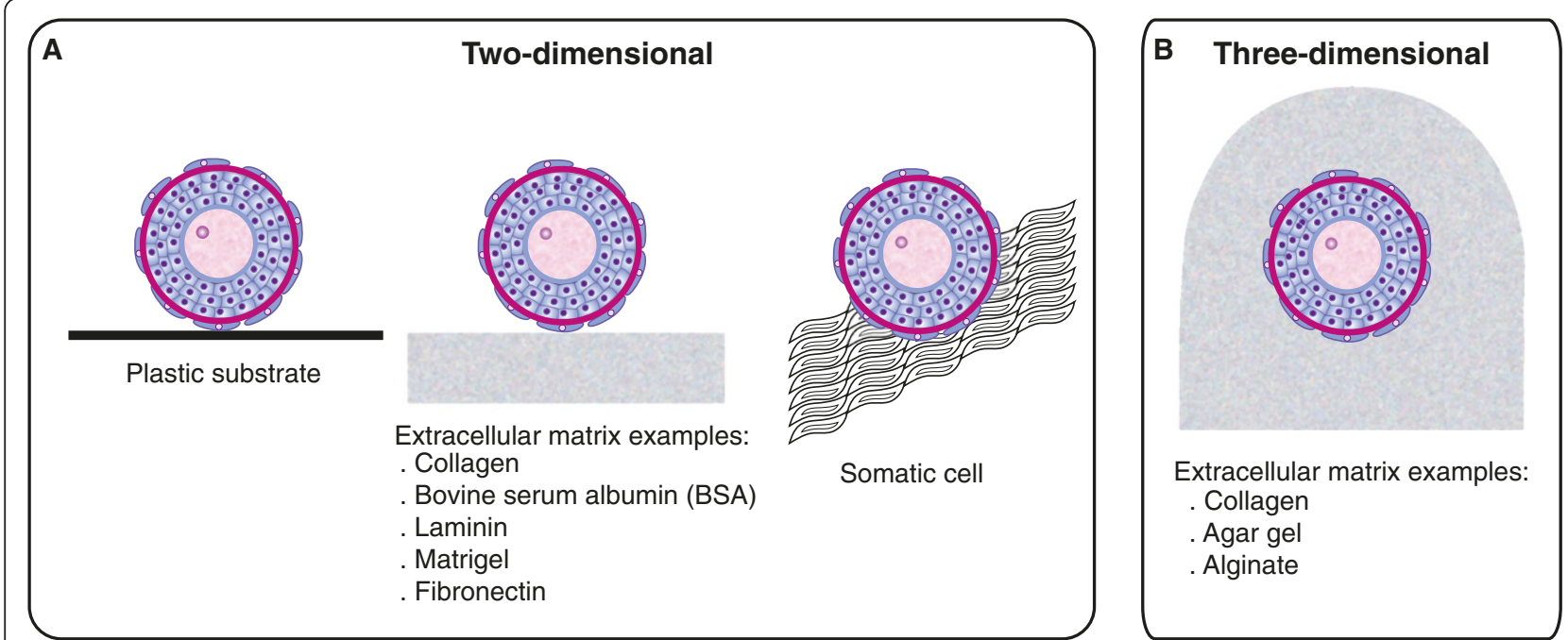

Figure 3 Schematic representation of the two- and three-dimensional culture systems. Schematic representation of the (A) two- and (B) three-dimensional culture systems utilized for bovine preantral follicles. 
Table 1 Chronological advances in in situ culture system of early bovine preantral follicles*

\begin{tabular}{|c|c|c|c|c|c|}
\hline Authors & $\begin{array}{l}\text { Duration of } \\
\text { culture (days) }\end{array}$ & $\begin{array}{c}\text { Type of } \\
\text { medium utilized }\end{array}$ & $\begin{array}{l}\text { Maintenance of } \\
\text { follicular survival } \\
\text { and/or viability }\end{array}$ & $\begin{array}{l}\text { Follicular activation } \\
\text { (from primordial to } \\
\text { transitional or } \\
\text { primary stage) }\end{array}$ & $\begin{array}{c}\text { Increase of } \\
\text { follicular and/or } \\
\text { oocyte diameter }\end{array}$ \\
\hline Peluso and Hirschel, 1988 & 2 & TCM-199 & Yes & Yes & Yes \\
\hline Wandji et al., 1996a & $0,2,4$, or 7 & Waymouth & Yes & Yes & Yes \\
\hline Braw-Tal and Yossefi, 1997 & 4 & a-MEM & - & - & Yes \\
\hline Fortune et al., 1998 & 7 or 14 & Waymouth & Yes & Yes & Yes \\
\hline Derrar et al., 2000 & 8 & Waymouth, a-MEM & Yes & Yes & - \\
\hline Gigli et al., 2006 & 7 & Waymouth & - & Yes & Yes \\
\hline Yang and Fortune, 2006 & 10 & Waymouth & - & Yes & Yes \\
\hline Yang and Fortune, 2007 & 10 & Waymouth & - & Yes & Yes \\
\hline Yang and Fortune, 2008 & 2 or 10 & Waymouth & - & Yes & - \\
\hline McLaughlin and Telfer, 2010 & 6 & McCoy's & Yes & Yes & Yes \\
\hline Andrade et al., 2012 & 8 & a-MEM & Yes & Yes & - \\
\hline Tang et al., 2012 & 22 & a-MEM & - & Yes & Yes \\
\hline
\end{tabular}

*All the results were compared with the fresh control group (Day 0).

\section{In vitro culture of isolated preantral follicles}

Although primordial and primary follicles can easily be isolated from bovine ovaries using mechanical or enzymatic methods, mostly small (diameter $\leq 150 \mu \mathrm{m}$ ) and large (diameter $>150 \mu \mathrm{m}$ ) secondary follicles have commonly been used for this in vitro culture system [37-40,79]. In the bovine species, several studies have used in vitro culture of isolated follicles (Table 2). The best results produced so far have been obtained from culture of large secondary follicles [22,37-40]. It has been reported that early secondary follicles (75 to $125 \mu \mathrm{m}$ in diameter) attached to the culture wells and created a monolayer, which resulted in flattened and damaged follicular structures [55]. Conversely, the culture of isolated large secondary follicles was able to maintain follicular viability, increase follicular diameter, and foster estradiol and progesterone production [65].

In general, isolated bovine preantral follicles have been cultured using well plates without mineral oil in a 2D culture system. In vitro culture without mineral oil has maintained follicular viability and increased antrum formation $[20,22,39,40]$ and estradiol production [22] in isolated bovine preantral follicles. Similarly, studies using mineral oil in a 2D culture system also have shown high follicular viability and antrum formation $[37,38,55]$, as well as an increase in estradiol production after in vitro culture [38].

A 3D culture system has been developed to culture isolated preantral follicles in mice [82-84], buffalo [85], cows $([65,86,87]$, Araújo et al., unpublished observations), and human [88] and nonhuman [17] primates. In this method, the follicles are cultured inside an extracellular matrix, which mimics the ovary and maintains the spherical morphology of the ovarian follicle and preserves the cell-cell and cell-matrix connections important for regulating follicle development in vivo [89-91]. The 3D culture system maintained high follicular viability and increased follicular diameter $[65,86]$ and steroid production after in vitro culture [65]. It is believed that $3 \mathrm{D}$ systems more effectively simulate physiological conditions because many cellular processes in organogenesis occur exclusively in three dimensions [82].

Improving in vitro growth of bovine preantral follicles Oocyte-secreted paracrine factors promote the proliferation, differentiation, and function of granulosa cells. Moreover, the development of the oocyte in vitro to a stage where normal embryonic development can be supported is dependent on the oocyte reaching the appropriate stage of development to respond to the endocrine and paracrine signals responsible for the induction of maturation [92]. Therefore, an elucidation of the bidirectional interplay between these two cell types is also important for the development of a successful culture system [4].

\section{Culture media}

Different commercial media have been used to culture bovine preantral follicles in vitro (Tables 1 and 2). However, based on literature reports there has been no standard, reliable culture medium for bovine preantral follicles. The most commonly used culture media are: $\alpha$-MEM [37-40,48], TCM-199 [39,55,56,93,94], and McCoy $[20,22,39,58,79,95,96]$. The lack of standardized protocols may affect in vitro follicle culture and can also explain the different results from several research groups. Among the commercial culture media, TCM-199 and $\alpha$-MEM have been the most commonly used to maintain follicular survival and viability and to improve the development of 
Table 2 Chronological advances in two and three dimensional (2D and 3D) in vitro culture systems for isolated bovine preantral follicles*

\begin{tabular}{|c|c|c|c|c|c|c|c|c|}
\hline Authors & $\begin{array}{l}\text { Duration } \\
\text { of culture } \\
\text { (days) }\end{array}$ & $\begin{array}{c}\text { Follicular } \\
\text { diameter }(\mu \mathrm{m})^{\dagger}\end{array}$ & $\begin{array}{l}\text { Type of } \\
\text { medium } \\
\text { utilized }\end{array}$ & $\begin{array}{c}\text { Culture system } \\
\text { description }\end{array}$ & $\begin{array}{l}\text { Maintenance } \\
\text { of follicular } \\
\text { survival and/or } \\
\text { viability }\end{array}$ & $\begin{array}{c}\text { Increase } \\
\text { of follicular } \\
\text { and/or oocyte } \\
\text { diameter }\end{array}$ & $\begin{array}{l}\text { Antrum } \\
\text { formation }\end{array}$ & $\begin{array}{c}\text { Steroid } \\
\text { secretion }\end{array}$ \\
\hline $\begin{array}{l}\text { Figueiredo et al., } \\
\text { 1994a }\end{array}$ & 5 & $30-70$ & a-MEM & $\begin{array}{l}\text { 2D-plastic substrate } \\
\text { (3 follicles/drop) }\end{array}$ & Yes & Yes & - & - \\
\hline $\begin{array}{l}\text { Figueiredo et al., } \\
\text { 1994b }\end{array}$ & 5 & $30-70$ & a-MEM & $\begin{array}{l}\text { 3D-collagen } \\
\text { (4 follicles/well) }\end{array}$ & Yes & Yes & - & - \\
\hline $\begin{array}{l}\text { Figueiredo et al., } \\
1995\end{array}$ & 1 & $30-70$ & a-MEM & $\begin{array}{l}\text { 2D-uncoated plastic } \\
\text { or coated with BSA, } \\
\text { Laminin, Fibronectin, } \\
\text { Matrigel, or Collagen } \\
\text { and 3D-Collagen }\end{array}$ & - & - & - & - \\
\hline $\begin{array}{l}\text { Wandji et al., } \\
\text { 1996b }\end{array}$ & 6 & $60-220$ & Waymouth & $\begin{array}{l}\text { 3D-agar gel (30-40 } \\
\text { follicles/drop) }\end{array}$ & Yes & Yes & - & E2 and P4 \\
\hline $\begin{array}{l}\text { Hulshof et al., } \\
1997\end{array}$ & 5 & $30-70$ & a-MEM & $\begin{array}{c}\text { 3D-collagen } \\
\text { (5 follicles/drop) }\end{array}$ & Yes & Yes & - & - \\
\hline $\begin{array}{l}\text { Schotanus et al., } \\
1997\end{array}$ & 8 & $30-80$ & TCM-199 & $\begin{array}{l}\text { 3D-collagen (5-10 } \\
\text { follicles/drop) }\end{array}$ & Yes & Yes & - & - \\
\hline $\begin{array}{l}\text { Katska and } \\
\text { Rynska, } 1998\end{array}$ & 23 & 75-195 & $\begin{array}{l}\text { TCM-199, } \\
\text { Menezo B2 }\end{array}$ & 2D-under mineral oil & Yes & Yes & - & - \\
\hline $\begin{array}{l}\text { Gutierrez et al., } \\
2000\end{array}$ & 28 & $166 \pm 2.2$ & McCoy's & $\begin{array}{l}\text { 2D-plastic substrate } \\
\text { (1 follicle/well) }\end{array}$ & - & Yes & Yes & - \\
\hline $\begin{array}{l}\text { Itoh and Hoshi, } \\
2000\end{array}$ & 30 & $30-70$ & TCM-199 & $\begin{array}{l}\text { 2D-somatic cells } \\
\text { (15-20 follicles/well) }\end{array}$ & Yes & Yes & - & - \\
\hline $\begin{array}{l}\text { McCaffery et al., } \\
2000\end{array}$ & 6 & $100-200$ & McCoy's & 2D-plastic substrate & - & Yes & Yes & - \\
\hline Saha et al., 2000 & 10 & $40-100$ & TCM-199 & 2D (1-3 follicles/well) & Yes & Yes & - & - \\
\hline $\begin{array}{l}\text { Thomas et al., } \\
2001\end{array}$ & 12 & $146 \pm 1.7$ & McCoy's & 2D-plastic substrate & - & Yes & - & E2 \\
\hline Itoh et al., 2002 & 13 & $145-170$ & TCM-199 & 3D-collagen & - & Yes & Yes & E2 \\
\hline Saha et al., 2002 & 7 & 120 & TCM-199 & $2 \mathrm{D}$ & Yes & Yes & No & - \\
\hline $\begin{array}{l}\text { Thomas et al., } \\
2007\end{array}$ & 6 & $145 \pm 0.6$ & McCoy's & $2 \mathrm{D}$ & - & Yes & No & E2 \\
\hline $\begin{array}{l}\text { McLaughlin et al., } \\
2010\end{array}$ & 8 & $157 \pm 3$ & McCoy's & $2 \mathrm{D}$ & - & Yes & Yes & - \\
\hline $\begin{array}{l}\text { McLaughlin and } \\
\text { Telfer, } 2010\end{array}$ & $12-15$ & $111 \pm 1.5$ & McCoy's & $2 \mathrm{D}$ & - & Yes & - & E2 \\
\hline $\begin{array}{l}\text { Rossetto et al., } \\
2012\end{array}$ & 16 & $>150$ & $\begin{array}{l}\text { a-MEM, TCM- } \\
\text { 199, McCoy's }\end{array}$ & 2D-plastic substrate & Yes & Yes & Yes & - \\
\hline $\begin{array}{l}\text { Rossetto et al., } \\
2013\end{array}$ & 18 & $>150$ & a-MEM & 2D-plastic substrate & Yes & Yes & Yes & - \\
\hline
\end{tabular}

*All the results were compared with the fresh control group (Day 0). Estradiol (E2) and Progesterone (P4) hormones.

${ }^{\dagger}$ At Day 0 of culture.

bovine follicles. A recent study compared TCM-199, McCoy, and $\alpha$-MEM under the same experimental conditions and demonstrated that TCM-199 was the best medium to culture bovine secondary follicles, based on the high percentage of viable follicles after in vitro culture [39]. However, this study also revealed that follicles cultured in $\alpha$-MEM or TCM-199 preserved at the ultrastructural level the cytoplasmic membrane and oocyte nucleus, and normally and uniformly distributed mitochondria and endoplasmic reticulum. Comparing
$\alpha-M E M$ with TCM-199 we found recently that $\alpha$-MEM can be used to replace TCM-199 for bovine preantral follicle culture if only progressive addition of medium without medium removal is used for medium change (Araújo et al., unpublished observations). These results provide new perspectives in order to identify the best culture system for each species, taking into consideration the base culture medium, supplements (hormones and growth factors), and medium replacement methods. 


\section{Basic supplements}

Substances such as pyruvate, glutamine, hypoxanthine [48], and ascorbic acid [95] have been used with success for the culture of bovine ovarian preantral follicles. Therefore, these substances have become part of the base medium used to culture ovarian follicles of several species. Pyruvate and glutamine are energy substrates and the addition of both substances to the culture medium increased the percentage of intact follicles [94]. Pyruvate was shown as a predominant substrate used by immature bovine oocytes [97] and isolated growing mouse oocytes [98]. Glutamine is an efficient energy substrate required for biomass synthesis [99] by bovine preantral follicles [48]. Hypoxanthine is a substance that has increased the number of morphologically normal oocytes [48], maintained oocyte-granulosa cell communication during the culture of mouse preantral follicles [61], prevented meiotic resumption [100], and promoted oocyte growth in vitro [101]. It has been suggested that hypoxanthine improves the utilization of additional energy substrates by maintaining interactions between the oocyte and the surrounding granulosa cells [48].

Another important substance that has been used in culture media is ascorbic acid. Ascorbic acid is a vitamin that acts as an antioxidant and is involved in processes of hormone secretion, gonadal tissue remodeling, and apoptosis [102]. It has also been associated with several processes during follicular and luteal development [95] because it accumulates in granulosa cells, theca interna cells, luteal cells, and oocytes [103-105]. Moreover, it was observed in vitro that ascorbic acid maintained follicle integrity in the absence of serum, reduced the incidence of cell death, and may participate in the regulation of extracellular matrix remodeling by increasing matrix metalloproteinases-9 (MMP-9) activity [95]. Additionally, the addition of ascorbic acid to the culture medium stimulates the activation of in vitro cultured primordial follicles in cattle and subsequent growth of activated follicles [106]. Therefore, the use of ascorbic acid is crucial for culture of isolated follicles because it ensures the integrity of the basement membrane of the follicles.

\section{Growth factors}

Ovarian follicular growth is controlled by complex interactions between the oocyte and the surrounding granulosa and theca cells, as well as by locally produced growth factors and hormones. In addition, the balance of stimulatory and suppressive factors dramatically affects the growth of granulosa cells of small preantral follicles in vitro [65]. Among the known major growth factors present in bovine ovarian cells are insulin-like growth factors (IGFs; [96]), fibroblast growth factors (FGFs; $[107,108]$ ), vascular endothelial growth factors (VEGFs; [34]), bone morphogenetic proteins (BMPs), and growth and differentiation factors
(GDFs; [74,109]). The following sections will describe only the growth factors which have been used in in vitro culture systems for bovine preantral follicles.

\section{Insulin-like growth factor-1 (IGF-1)}

The IGF-1 binding ontogeny [110] and its type 1 receptor mRNA have been demonstrated in the oocytes and granulosa and theca cells of bovine preantral follicles [111]. In addition, IGF binding protein-2 (IGFBP-2) mRNA has been detected in granulosa cells and oocytes, and IGFBP-3 mRNA in oocytes from bovine preantral follicles [112]. During the stages of antral and preovulatory follicles, IGF1 mRNA has been detected in bovine granulosa [113] and theca cells [111], indicating that IGF-1 is important during the later stages of folliculogenesis (e.g., in relation to LH responsiveness [10].

IGF-1 has been identified as a stimulatory growth factor for bovine follicular and oocyte growth, as well as for antrum formation during prolonged culture [20,59]. Long-term in vitro culture may allow the differentiation of granulosa cells by IGF-1, which acts as a stimulator of follicular development. Follicular growth [96], antral cavity formation $[40,58,96]$, and estradiol production were observed after using IGF-1 in the in vitro culture of bovine preantral follicles. Conversely, McCaffery et al. [58] observed that treatment of immature follicles with IGF-1 resulted in precocious differentiation, which might have retarded follicular growth and cell proliferation. Recently, Rossetto et al. [40] showed that addition of IGF-1 to the culture medium of bovine preantral follicles had no effect on the follicular morphology and antrum formation. Similarly, we observed that IGF-1 did not interfere in any end point, including the estradiol concentrations, evaluated during the in vitro culture of bovine secondary follicles (Araújo et al., unpublished observations). Therefore, the action of IGF-1 in bovine oocyte and follicular development is strictly regulated by the developmental stage, period of culture, and concentration of IGF-1 used [114].

\section{Basic fibroblast growth factor (bFGF)}

Immunoreactivity, bioactivity, and mRNA of bFGF are present in bovine granulosa cells [115]. Both bFGF alone and bFGF in combination with FSH allowed the maintenance of follicular survival, promoted in vitro growth of granulosa cells, and increased the diameter of bovine preantral follicles. However, when bFGF was combined with transforming growth factor $\beta$ (TGF- $\beta$ ), there was an inhibition of the stimulatory effect of bFGF on follicular diameter and a decrease in follicular survival [115]. Although bFGF alone stimulated estradiol and progesterone production during in vitro culture of bovine preantral follicles, it suppressed FSH-stimulated progesterone production [65]. These results suggest that bFGF antagonizes, at least in 
some aspects, the FSH-mediated cytodifferentiation of cultured bovine preantral follicles.

\section{Vascular endothelial growth factor (VEGF)}

VEGF has been known as a regulator of the various phases of follicle development [116]. Yang and Fortune [34] demonstrated that the mRNA for both VEGF receptors (flt-1 or VEGFR-1 and flk-1 or VEGFR-2), as well as for the VEGF ligand, were expressed in the fetal bovine ovary at day 90 of gestation. However, mRNA expression for the VEGF ligand increased when the first secondary follicles were observed at day 210 of gestation [34]. As the follicle grows and the antral cavity becomes filled with follicular fluid, VEGF production increases and the follicular fluid becomes rich in VEGF $[117,118]$. These aspects have been confirmed by increasing of the VEGF ligand (mRNA and protein) with the proliferation of microvessels, progression of gestation, and ovarian development [34].

The role of VEGF in promoting the primary to secondary follicle transition has been demonstrated in vitro during culture of fetal bovine ovarian tissue [34]. In goats, VEGF has been shown to be crucial to the in vitro growth of preantral follicles and their oocytes enclosed in ovarian tissue [119], and to meiosis progression during the maturation of oocytes grown from secondary follicles cultured in vitro [42]. Recently, we have demonstrated that VEGF increases antrum formation and follicular growth rate after in vitro culture of bovine preantral follicles (Araújo et al., unpublished observations). Taken together, these results lead us to believe that VEGF may be an excellent constituent for the in vitro culture media for bovine secondary follicles.

\section{Hormones}

There seems to exist an overall consensus that preantral follicles can develop in the absence of gonadotropins. However, the use of gonadotropins for in vitro culture has been important for obtaining optimal development of preantral follicles. Treatment of large, isolated preantral follicles with FSH stimulated granulosa cell proliferation and antrum formation [37-39,65,79]. Moreover, hormones such as FSH $[38,39,79]$, and activin stimulated steroidogenesis in bovine isolated preantral follicles $[22,39,79]$. The following sections will describe only the hormones which have been used in in vitro culture systems for bovine preantral follicles and ovarian cells.

\section{Activin}

Activin is a proteic hormone that enhances FSH biosynthesis and secretion. Activin and its receptor are expressed on theca and granulosa cells, and oocytes of bovine preantral follicles [120]. It is composed of two beta subunits, $\mathrm{A}$ and $\mathrm{B}$, and exists as a homo- (A and $\mathrm{B})$ or heterodimer
(AB) with activin-A as the predominant isoform. Activins are involved in primordial follicle activation in vitro [121], preantral follicle development [120,122-124], granulosa cell proliferation, antral cavity formation, maintenance of normal oocyte morphology, and interactions between the oocyte and granulosa cells [22]. Polarized expression of cell contact interactions promoted by activin supports ongoing folliculogenesis, which is characterized by increased peripheral granulosa cell adhesion to the basement membrane and retention of adhesion at the surface of the ZP [22].

Although activin has caused a significant increase in the size of follicles and estradiol concentrations in immature mice, in adult mice it did not change the follicle diameter and completely blocked the action of FSH on both follicle diameter and estradiol concentration [125]. In sheep, the activin promoted preantral follicle and oocyte growth in vitro, but did not accelerate follicle differentiation or have any effect on antrum formation or follicle survival. Moreover, activin and FSH interacted positively to stimulate the follicle growth and granulosa proliferation of bovine preantral follicles [120]. All these results indicate that activin has a paracrine role through proliferative and cytodifferentiative action on granulosa cells and that its action is age and FSH dependent.

\section{Follicle-stimulating hormone (FSH)}

Gonadotropins seem to be important for the optimal development of preantral follicles in vitro. FSH in particular is considered a critical hormone for the survival of large secondary follicles [126] and its receptor (FSH-R) has been observed in granulosa cells of bovine preantral follicles (primary and secondary; [110]). In vitro culture of bovine isolated preantral follicles with FSH stimulated an increase in follicular diameter [65,120], granulosa cell proliferation by BrdU-label [120], and progesterone [65] and estradiol secretion [22]. Moreover, FSH maintained normal oocyte morphology and interactions between the oocyte and granulosa cells after in vitro culture of bovine secondary follicles [22]. Wandji et al. [65] observed that large preantral follicles $(150$ to $220 \mu \mathrm{m})$ produced more progesterone in response to FSH than smaller (60 to $179 \mu \mathrm{m})$ preantral follicles. These findings indicated that the responsiveness to FSH increases as the bovine follicles develop.

\section{Growth hormone (GH)}

Among metabolism-related endocrine factors, $\mathrm{GH}$ has been shown to be a crucial factor for follicular development in the mammalian ovary [127]. Both fetal and adult bovine ovaries revealed distinct amounts of GH receptor (GHR) and its transcript in the oocytes of primordial and primary follicles, as well as mRNA for GHR in secondary and tertiary follicles. These results support the 
concept that GHR is involved in the development and differentiation of primordial follicles in both prenatal and postnatal life [128].

In vivo, GH may stimulate specific follicle populations selectively. GH inhibited the development of preovulatory follicles and stimulated the growth of the second-largest follicle in heifers [129]. GHR immunoreactivity and mRNA encoding GHR in granulosa cells, theca cells and luteal cells of the bovine ovary [128] suggests the GH action by means of the detection of GH binding activity. Moreover, GHR expression increases in the granulosa cells when the follicles become estrogen-active, even when compared to preovulatory follicles [128]. Thus, the increase in GHR expression in these follicles may be regulated by estradiol [128]. The negative interaction between $\mathrm{GH}$ and estradiol during later folliculogenesis seems to be true; however, this effect seems to be positive during early folliculogenesis, since the addition of $\mathrm{GH}$ to the culture medium of bovine preantral follicle increased the estradiol concentrations (Araújo et al., unpublished observations). In addition, bovine granulosa cells' expression of mRNA for GHR was stimulated in vitro by FSH [127]. Also, GH has been shown to enhance cell proliferation and steroidogenesis of cultured granulosa cells in cattle [130], suggesting an important role for $\mathrm{GH}$ in the regulation of granulosa cell proliferation and follicular growth.

\section{Insulin}

Among the endocrine factors, insulin is a crucial hormone for follicular development [127], granulosa cell function, and ovulation [131]. Additionally, insulin may regulate various intracellular processes in the follicle, such as amino acid transport, lipid metabolism, gene transcription, and protein synthesis [132]. Insulin acts through its own receptor, which first appears in the granulosa cells of small bovine antral follicles [131]. Insulin receptor is widely distributed throughout all ovarian compartments, including granulosa and theca cells and stromal tissue $[127,131]$. In addition, the concentrations of insulin in follicular fluid are constant at all follicular developmental stages [127].

Infusion of insulin in beef heifers increased the diameter of the dominant follicle [133]. High levels of insulin receptor mRNA expression in granulosa cells of preovulatory follicles seem to be necessary for development of the ovulatory stage [127]. The presence of insulin receptor in small antral follicles, together with its absence in preantral follicles, indicates the involvement of insulin, and the acquisition of its receptor, during early follicular growth in bovine [131]. This hypothesis has been supported by the fact that increased dietary intake of insulin was associated with recruitment of small follicles $(<4 \mathrm{~mm})$, but did not affect follicle selection (medium: 4-8 $\mathrm{mm}$ ) or dominant (large: $>8 \mathrm{~mm}$ ) follicles [134].
In vitro, insulin has been shown to be essential for follicle culture. Absence of insulin in the culture medium resulted in follicle degeneration [94]. Gutierrez et al. [20] demonstrated that bovine preantral follicles grew for a long period in culture, even in the absence of tropic hormones, but in the presence of insulin. Considering that type 1 IGF-1 receptor is present in oocytes and granulosa and theca cells of bovine preantral follicles [111], and that insulin competes with the IGF receptors, the follicular growth effect was probably promoted by the interaction of insulin and the type 1 IGF-1 receptor.

\section{Estrogens and androgens}

Steroid hormones have been shown to be involved in growth of bovine preantral follicles in vitro (estradiol: [135]; testosterone: [80]. Moreover, its receptors have been reported to be present in bovine ovaries [80]. Addition of estradiol in vitro increased follicular diameter of bovine isolated preantral follicles without affecting the proliferation of granulosa cells [135]. Furthermore, a combined action of insulin, estradiol, and human chorionic gonadotropin (hCG) promoted granulosa cell proliferation, as well as the growth of primordial follicles into primary follicles after $48 \mathrm{~h}$ of in vitro culture of bovine ovarian cortical tissue [68]. In addition, treatment with estradiol in vivo stimulated activation of primordial follicles, and its combination with bovine somatotropin (bST) decreased the rate of atresia of primary follicles [136]. Moreover, testosterone was reported to promote growth of primary to secondary follicles after in vitro culture of bovine cortical fragments [80]. Using immunohistochemistry to detect androgen receptors (AR) the previous authors also demonstrated that granulosa and theca cells of only secondary and tertiary follicles exhibited AR staining. Furthermore, estradiol production was substantially reduced when an anti-androgen antibody was used during in vitro culture of mouse preantral follicles [137]; however, this effect was neutralized with androstenedione, which significantly increased estradiol production.

\section{Final considerations}

Several studies of bovine folliculogenesis have examined the aspects of in vitro follicular development. However, it is still not clear which culture medium needs to be used to culture bovine preantral follicles, as well as which growth factors and hormones could influence follicular development. Moreover, it will be important to have an optimum and standard culture system for bovine follicles, either using two- or three-dimensional approaches. A culture system to be selected needs to affect positively follicular morphology, survival, proliferation, steroidogenesis, and gene expression. Furthermore, it is important to reevaluate the effect of growth factors and/ 
or hormones on follicular growth. The follicle microenvironment must be considered, as well as the role of growth factors and hormones and their respective signaling pathways during in vitro follicular development. Additionally, factors such as age (immature or adult) of the animals, follicular category (early or late preantral follicles, or antral follicles) to be used, and system of in vitro follicular culture (two- or three-dimensional) should be considered very important sources of data variation.

\section{Abbreviations \\ BMPs: Bone morphogenetic proteins; BrdU-label: Bromodeoxyuridine; DNAse: Deoxyribonuclease; FGFs: Fibroblast growth factors; flk-1 or VEGFR-2: Kinase domain receptor (VEGF receptor 2); flt-1 or VEGFR-1: Fms-like tyrosine kinase-1 (VEGF receptor 1); FSH: Follicle-stimulating hormone; GDFs: Growth and differentiation factors; GH: Growth hormone; GHR: GH receptor; IGFBP-2: IGF binding protein-2; IGFs: Insulin-like growth factors; LH: Luteinizing hormone; a-MEM: Minimum essential medium alpha modification; MMP-9: Matrix metalloproteinases-9; OPU: Ovum pick-up technique; TCM-199: Tissue culture medium-199; TGF- $\beta$ : Transforming growth factor $\beta$; VEGF: Vascular endothelial growth factor; ZP: Zona pellucida; \\ 2D: Two-dimensional system; 3D: Three-dimensional system. \\ Competing interests \\ The authors declare that they have no competing interests. \\ Authors' contributions \\ VRA and ELG conceived the idea; VRA did the literature survey; MOG, VRA $J R F$, and ELG read and analyzed independently selected manuscripts; VRA and MOG drafted the manuscript; JRF and ELG corrected versions of the manuscript, and ELG edited the final document. All authors read and approved the final manuscript.}

\section{Acknowledgments}

Southern Illinois University, Carbondale, IL, USA and The National Council for Scientific and Technological Development (CNPq), Brazil. Araújo VR was the recipient of a PhD scholarship from CNPq, Brazil.

\section{Author details}

${ }^{1}$ Department of Animal Science, Food and Nutrition, Southern Illinois University, 1205 Lincoln Drive, MC 4417, Carbondale, IL 62901, USA.

2 Laboratory of Manipulation of Oocytes and Preantral Follicles (LAMOFOPA), Veterinary Faculty, State University of Ceará, Av. Paranjana 1700, Campus do Itaperi, Fortaleza, CE 60740-903, Brazil.

Received: 15 April 2014 Accepted: 8 August 2014

Published: 13 August 2014

\section{References}

1. Gougeon A: The early stages of follicular growth. In Biology and pathology of the oocyte. Edited by Trounson AO, Gosden RG. Cambridge, UK: University Press; 2003:29-43.

2. Cortvrindt R, Smitz J: In vitro follicle growth: achievements in mammalian species. Reprod Domest Anim 2001, 36:3-9.

3. Aerts JM, Oste M, Bols PE: Development and practical applications of a method for repeated transvaginal, ultrasound-guided biopsy collection of the bovine ovary. Theriogenology 2005, 64:947-957.

4. Aerts JMJ, Martinez-Madrid B, Flothmann K, De Clercq JBP, Van Aelst S, Bols PEJ: Quantification and viability assessment of isolated bovine primordial and primary ovarian follicles retrieved through a standardized biopsy pick-up procedure. Reprod Domest Anim 2008, 43:360-366

5. Bols PE, Vandenheede JM, Van Soom A, de Kruif A: Transvaginal ovum pick-up (OPU) in the cow: a new disposable needle guidance system. Theriogenology 1995, 43:677-687.

6. Haag KT, Magalhaes-Padilha DM, Fonseca GR, Wischral A, Gastal MO, King SS, Jones KL, Figueiredo JR, Gastal EL: Quantification, morphology, and viability of equine preantral follicles obtained via the Biopsy Pick-Up method. Theriogenology 2013, 79:599-609.
7. Haag KT, Magalhaes-Padilha DM, Fonseca GR, Wischral A, Gastal MO, King $\mathrm{SS}$, Jones KL, Figueiredo JR, Gastal EL: In vitro culture of equine preantral follicles obtained via the Biopsy Pick-Up method. Theriogenology 2013, 79:911-917.

8. Haag KT, Magalhaes-Padilha DM, Fonseca GR, Wischral A, Gastal MO, King SS, Jones KL, Figueiredo JR, Gastal EL: Equine preantral follicles obtained via the Biopsy Pick-Up method: histological evaluation and validation of a mechanical isolation technique. Theriogenology 2013, 79:735-743.

9. Abir R, Ao A, Zhang XY, Garor R, Nitke S, Fisch B: Vascular endothelial growth factor $A$ and its two receptors in human preantral follicles from fetuses, girls, and women. Fertil Steril 2010, 93:2337-2347.

10. Ginther OJ, Gastal EL, Gastal MO, Bergfelt DR, Baerwald AR, Pierson RA: Comparative study of the dynamics of follicular waves in mares and women. Biol Reprod 2004, 71:1195-1201.

11. Gastal EL: Ovulation: 2. Ultrasonographic morphology of the preovulatory follicle. In Equine Reproduction. 2nd edition. Edited by McKinnon AO, Squires EL, Vaala W, Varner D. Oxford: Wiley-Blackwell; 2011:2032-2054.

12. Baerwald AR: Human antral folliculogenesis: what we have learned from bovine and equine models. Anim Reprod 2009, 6:20-29.

13. Gupta PS, Ramesh HS, Manjunatha BM, Nandi S, Ravindra JP: Production of buffalo embryos using oocytes from in vitro grown preantral follicles. Zygote 2008, 16:57-63.

14. Arunakumari G, Shanmugasundaram N, Rao VH: Development of morulae from the oocytes of cultured sheep preantral follicles. Theriogenology 2010, 74:884-894.

15. Luz VB, Araujo VR, Duarte AB, Celestino JJ, Silva TF, Magalhaes-Padilha DM, Chaves RN, Brito IR, Almeida AP, Campello CC, Feltrin C, Bertolini M, Santos $R R$, Figueiredo JR: Eight-cell parthenotes originated from in vitro grown sheep preantral follicles. Reprod Sci 2012, 19:1219-1225.

16. Magalhaes DM, Duarte AB, Araujo VR, Brito IR, Soares TG, Lima IM, Lopes CA Campello CC, Rodrigues AP, Figueiredo JR: In vitro production of a caprine embryo from a preantral follicle cultured in media supplemented with growth hormone. Theriogenology 2011, 75:182-188.

17. Xu J, Lawson MS, Yeoman RR, Pau KY, Barrett SL, Zelinski MB, Stouffer RL: Secondary follicle growth and oocyte maturation during encapsulated three-dimensional culture in rhesus monkeys: effects of gonadotrophins, oxygen and fetuin. Hum Reprod 2011, 26:1061-1072.

18. Eppig JJ, O'Brien MJ: Development in vitro of mouse oocytes from primordial follicles. Biol Reprod 1996, 54:197-207.

19. O'Brien MJ, Pendola JK, Eppig JJ: A revised protocol for in vitro development of mouse oocytes from primordial follicles dramatically improves their developmental competence. Biol Reprod 2003, 68:1682-1686.

20. Gutierrez CG, Ralph JH, Telfer EE, Wilmut I, Webb R: Growth and antrum formation of bovine preantral follicles in long-term culture in vitro. Biol Reprod 2000, 62:1322-1328.

21. Eppig JJ, Wigglesworth K, Pendola FL: The mammalian oocyte orchestrates the rate of ovarian follicular development. Proc Natl Acad Sci U S A 2002, 99:2890-2894.

22. McLaughlin M, Bromfield JJ, Albertini DF, Telfer EE: Activin promotes follicular integrity and oogenesis in cultured pre-antral bovine follicles. Mol Hum Reprod 2010, 16:644-653.

23. Russe l: Oogenesis in cattle and sheep. Bibl Anat 1983, 24:77-92.

24. Lussier JG, Matton P, Dufour JJ: Growth rates of follicles in the ovary of the cow. J Reprod Fertil 1987, 81:301-307.

25. Braw-Tal R, Yossefi S: Studies in vivo and in vitro on the initiation of follicle growth in the bovine ovary. J Reprod Fertil 1997, 109:165-171.

26. Erickson BH: Development and radio-response of the prenatal bovine ovary. J Reprod Fertil 1966, 11:97-105.

27. Yang MY, Fortune JE: The capacity of primordial follicles in fetal bovine ovaries to initiate growth in vitro develops during mid-gestation and is associated with meiotic arrest of oocytes. Biol Reprod 2008, 78:1153-1161.

28. Baker TG, Franchi LL: The fine structure of chromosomes in bovine primordial oocytes. J Reprod Fertil 1967, 14:511-513.

29. van den Hurk R, Bevers MM, Beckers JF: In-vivo and in-vitro development of preantral follicles. Theriogenology 1997, 47:73-82.

30. Hulshof SC, Figueiredo JR, Beckers JF, Bevers MM, van den Hurk R: Isolation and characterization of preantral follicles from foetal bovine ovaries. Vet Q 1994, 16:78-80.

31. Fair T, Hulshof SC, Hyttel P, Greve T, Boland M: Oocyte ultrastructure in bovine primordial to early tertiary follicles. Anat Embryol (Berl) 1997, 195:327-336. 
32. Fair T: Follicular oocyte growth and acquisition of developmental competence. Anim Reprod Sci 2003, 78:203-216.

33. Rankin TL, O'Brien M, Lee E, Wigglesworth K, Eppig J, Dean J: Defective zonae pellucidae in Zp2-null mice disrupt folliculogenesis, fertility and development. Development 2001, 128:1119-1126.

34. Yang MY, Fortune JE: Vascular endothelial growth factor stimulates the primary to secondary follicle transition in bovine follicles in vitro. Mol Reprod Dev 2007, 74:1095-1104

35. Carambula SF, Goncalves PB, Costa LF, Figueiredo JR, Wheeler MB, Neves JP, Mondadori RG: Effect of fetal age and method of recovery on isolation of preantral follicles from bovine ovaries. Theriogenology 1999, 52:563-571.

36. McNatty KP, Fidler AE, Juengel JL, Quirke LD, Smith PR, Heath DA, Lundy T, O'Connell A, Tisdall DJ: Growth and paracrine factors regulating follicular formation and cellular function. Mol Cell Endocrinol 2000, 163:11-20.

37. Araujo VR, Gastal MO, Fiqueiredo JR, Gastal EL: Effect of addition of medium without change during in vitro culture of bovine preantral follicles (Abstract). In 45th Annual Meeting of the Society for the Study of Reproduction (SSR). Pennsylvania, USA: State College; 2012.

38. Araújo VR, Wischral A, Gastal MO, Figueiredo JR, Gastal EL: In vitro estradiol production by bovine secondary follicles using two different culture systems. In IV International Symposium on Animal Biology of Reproduction (ISABR). Campinas, SP, Brazil: Anim Reprod; 2012:852.

39. Rossetto R, Saraiva MV, dos Santos RR, da Silva CM, Faustino LR, Chaves RN, Brito IR, Rodrigues GQ, Lima IM, Donato MA, Donato MA, Peixoto CA, de Figueiredo JR: Effect of medium composition on the in vitro culture of bovine pre-antral follicles: morphology and viability do not guarantee functionality. Zygote 2013, 21:125-128.

40. Rossetto R, Santos RR, Silva GM, Duarte ABG, Campello CC, Figueiredo JR: Comparative study on the in vitro development of caprine and bovine preantral follicles. Small Ruminant Res 2013, 113:167-170.

41. Araújo V, Chaves R, Graca Duarte A, de Hollanda Celestino JJ, da Silva GM, Fernandes DD, de Matos MH T, Campello CC, de Figueiredo JR: Effect of culture medium replacement protocol on the in vitro development of isolated caprine secondary follicles. Small Ruminant Res 2011, 95:139-143.

42. Araujo VR, Silva GM, Duarte AB, Magalhaes DM, Almeida AP, Goncalves RF, Bruno JB, Silva TF, Campello CC, Rodrigues AP, Fiqueiredo JR: Vascular endothelial growth factor-A(165) (VEGF-A(165)) stimulates the in vitro development and oocyte competence of goat preantral follicles. Cell Tissue Res 2011, 346:273-281.

43. Fiqueiredo JR, Hulshof SC, Van den Hurk R, Ectors FJ, Fontes RS, Nusgens B, Bevers MM, Beckers JF: Development of a combined new mechanical and enzymatic method for the isolation of intact preantral follicles from fetal, calf and adult bovine ovaries. Theriogenology 1993, 40:789-799.

44. Nuttinck F, Mermillod P, Massip A, Dessy F: Characterization of in vitro growth of bovine preantral ovarian follicles: a preliminary study. Theriogenology 1993, 39:811-821.

45. Jewgenow K, Goritz F: The recovery of preantral follicles from ovaries of domestic cats and their characterization before and after culture. Anim Reprod Sci 1995, 39:285-297.

46. Jewgenow K: Role of media, protein and energy supplements on maintenance of morphology and DNA-synthesis of small preantral domestic cat follicles during short-term culture. Theriogenology 1998, 49:1567-1577.

47. van den Hurk R, Spek ER, Hage WJ, Fair T, Ralph JH, Schotanus K: Ultrastructure and viability of isolated bovine preantral follicles. Hum Reprod Update 1998, 4:833-841.

48. Figueiredo JR, Hulshof SC, Van den Hurk R, Nusgens B, Bevers MM, Ectors FJ, Beckers JF: Preservation of oocyte and granulosa cell morphology in bovine preantral follicles cultured in vitro. Theriogenology 1994, 41:1333-1346.

49. Woodley DT, Rao CN, Hassell JR, Liotta LA, Martin GR, Kleinman HK: Interactions of basement membrane components. Biochim Biophys Acta 1983, 761:278-283

50. Gospodarowicz D, Greenburg G, Birdwell CR: Determination of cellular shape by the extracellular matrix and its correlation with the control of cellular growth. Cancer Res 1978, 38:4155-4171.

51. Figueiredo JR, Hulshof SC, Thiry M, Van den Hurk R, Bevers MM, Nusgens B, Beckers JF: Extracellular matrix proteins and basement membrane: their identification in bovine ovaries and significance for the attachment of cultured preantral follicles. Theriogenology 1995, 43:845-858.

52. Lucci CM, Rumpf R, Figueiredo JR, Bao SN: Zebu (Bos indicus) ovarian preantral follicles: morphological characterization and development of an efficient isolation method. Theriogenology 2002, 57:1467-1483.
53. Lucci CM, Amorim CA, Bao SN, Figueiredo JR, Rodrigues AP, Silva JR, Goncalves PB: Effect of the interval of serial sections of ovarian tissue in the tissue chopper on the number of isolated caprine preantral follicles. Anim Reprod Sci 1999, 56:39-49.

54. Amorim CA, Lucci CM, Rodrigues AP, Carvalho FC, Figueiredo JR, Rondina D, Cecchi R, Giorgetti A, Martini A, Goncalves PB: Quantitative and qualitative analysis of the effectiveness of a mechanical method for the isolation of preantral follicles from ovine ovaries. Theriogenology 2000, 53:1251-1262.

55. Katska $L$, Rynska B: The isolation and in vitro culture of bovine preantral and early antral follicles of different size classes. Theriogenology 1998, 50:213-222.

56. Saha S, Shimizu M, Geshi M, Izaike Y: Comparison of enzymatic and mechanical methods or the collection of bovine preantral follicles. Anim Sci 2002, 74:155-161.

57. Gougeon A: Regulation of ovarian follicular development in primates: facts and hypotheses. Endocr Rev 1996, 17:121-155.

58. McCaffery FH, Leask R, Riley SC, Telfer EE: Culture of bovine preantral follicles in a serum-free system: markers for assessment of growth and development. Biol Reprod 2000, 63:267-273.

59. Itoh $\mathrm{T}$, Kacchi $\mathrm{M}, \mathrm{Abe} \mathrm{H}$, Sendai $\mathrm{Y}$, Hoshi H: Growth, antrum formation, and estradiol production of bovine preantral follicles cultured in a serum-free medium. Biol Reprod 2002, 67:1099-1105.

60. Telfer EE: The development of methods for isolation and culture of preantral follicles from bovine and porcine ovaries. Theriogenology 1996, 45:101-110.

61. Eppig JJ, Downs SM: The effect of hypoxanthine on mouse oocyte growth and development in vitro: maintenance of meiotic arrest and gonadotropin-induced oocyte maturation. Dev Biol 1987, 119:313-321.

62. Greenwald GS, Moor RM: Isolation and preliminary characterization of pig primordial follicles. J Reprod Fertil 1989, 87:561-571.

63. Roy SK, Treacy BJ: Isolation and long-term culture of human preantral follicles. Fertil Steril 1993, 59:783-790.

64. Roy SK, Greenwald GS: An enzymatic method for dissociation of intact follicles from the hamster ovary: histological and quantitative aspects. Biol Reprod 1985, 32:203-215.

65. Wandji SA, Srsen V, Voss AK, Eppig JJ, Fortune JE: Initiation in vitro of growth of bovine primordial follicles. Biol Reprod 1996, 55:942-948

66. Schmidt KL, Byskov AG, Nyboe Andersen A, Muller J, Yding Andersen C: Density and distribution of primordial follicles in single pieces of cortex from 21 patients and in individual pieces of cortex from three entire human ovaries. Hum Reprod 2003, 18:1158-1164.

67. Thomas FH, Walters KA, Telfer EE: How to make a good oocyte: an update on in-vitro models to study follicle regulation. Hum Reprod Update 2003, 9:541-555.

68. Peluso JJ, Hirschel MD: Factors controlling the growth of bovine primary and preantral follicles in perifusion culture. Theriogenology 1988, 30:537-546.

69. Nilsson E, Parrott JA, Skinner MK: Basic fibroblast growth factor induces primordial follicle development and initiates folliculogenesis. Mol Cell Endocrinol 2001, 175:123-130

70. Wandji SA, Eppig JJ, Fortune JE: FSH and growth factors affect the growth and endocrine function in vitro of granulosa cells of bovine preantral follicles. Theriogenology 1996, 45:817-832.

71. Fortune JE, Kito S, Wandji SA, Srsen V: Activation of bovine and baboon primordial follicles in vitro. Theriogenology 1998, 49:441-449.

72. Derrar N, Price CA, Sirard MA: Effect of growth factors and co-culture with ovarian medulla on the activation of primordial follicles in explants of bovine ovarian cortex. Theriogenology 2000, 54:587-598.

73. Gigli I, Byrd DD, Fortune JE: Effects of oxygen tension and supplements to the culture medium on activation and development of bovine follicles in vitro. Theriogenology 2006, 66:344-353.

74. Tang K, Yang WC, Li X, Wu CJ, Sang L, Yang LG: GDF-9 and bFGF enhance the effect of FSH on the survival, activation, and growth of cattle primordial follicles. Anim Reprod Sci 2012, 131:129-134.

75. Silva JR, van den Hurk R, de Matos MH, dos Santos RR, Pessoa C, de Moraes MO, de Figueiredo JR: Influences of FSH and EGF on primordial follicles during in vitro culture of caprine ovarian cortical tissue. Theriogenology 2004, 61:1691-1704.

76. Matos MH, Lima-Verde IB, Luque MC, Maia JE Jr, Silva JR, Celestino JJ, Martins FS, Bao SN, Lucci CM, Figueiredo JR: Essential role of follicle stimulating hormone in the maintenance of caprine preantral follicle viability in vitro. Zygote 2007, 15:173-182. 
77. Wandji SA, Srsen V, Nathanielsz PW, Eppig JJ, Fortune JE: Initiation of growth of baboon primordial follicles in vitro. Hum Reprod 1997 12:1993-2001

78. Hovatta O, Wright C, Krausz T, Hardy K, Winston RM: Human primordial, primary and secondary ovarian follicles in long-term culture: effect of partial isolation. Hum Reprod 1999, 14:2519-2524.

79. McLaughlin M, Telfer EE: Oocyte development in bovine primordial follicles is promoted by activin and FSH within a two-step serum-free culture system. Reproduction 2010, 139:971-978.

80. Yang MY, Fortune JE: Testosterone stimulates the primary to secondary follicle transition in bovine follicles in vitro. Biol Reprod 2006, 75:924-932

81. Telfer EE, McLaughlin M, Ding C, Thong KJ: A two-step serum-free culture system supports development of human oocytes from primordial follicles in the presence of activin. Hum Reprod 2008, 23:1151-1158.

82. Xu M, Kreeger PK, Shea LD, Woodruff TK: Tissue-engineered follicles produce live, fertile offspring. Tissue Eng 2006, 12:2739-2746.

83. Oktem O, Oktay $\mathrm{K}$ : The role of extracellular matrix and activin-A in in vitro growth and survival of murine preantral follicles. Reprod Sci 2007, 14:358-366.

84. Desai N, Abdelhafez F, Calabro A, Falcone T: Three dimensional culture of fresh and vitrified mouse pre-antral follicles in a hyaluronan-based hydrogel: a preliminary investigation of a novel biomaterial for in vitro follicle maturation. Reprod Biol Endocrinol 2012, 10:29.

85. Sharma GT, Dubey PK, Meur SK: Survival and developmental competence of buffalo preantral follicles using three-dimensional collagen gel culture system. Anim Reprod Sci 2009, 114:115-124.

86. Figueiredo JR, Hulshof SCJ, van den Hurk R, Bevers MM, Thiry M, Nusgens B, Beckers JF: The physiological status of the ovarian donor affects in vitro development of isolated bovine. Theriogenology 1994, 42:1303-1310.

87. Schotanus K, Hage WJ, Vanderstichele H, van den Hurk R: Effects of conditioned media from murine granulosa cell lines on the growth of isolated bovine preantral follicles. Theriogenology 1997, 48:471-483.

88. Hovatta O, Silye R, Abir R, Krausz T, Winston RM: Extracellular matrix improves survival of both stored and fresh human primordial and primary ovarian follicles in long-term culture. Hum Reprod 1997, 12:1032-1036.

89. Pangas SA, Saudye H, Shea LD, Woodruff TK: Novel approach for the three-dimensional culture of granulosa cell-oocyte complexes. Tissue Eng 2003, 9:1013-1021.

90. Kreeger PK, Fernandes NN, Woodruff TK, Shea LD: Regulation of mouse follicle development by follicle-stimulating hormone in a three-dimensional in vitro culture system is dependent on follicle stage and dose. Biol Reprod 2005, 73:942-950.

91. West ER, Xu M, Woodruff TK, Shea LD: Physical properties of alginate hydrogels and their effects on in vitro follicle development. Biomaterials 2007, 28:4439-4448.

92. Telfer EE, Binnie JP, McCaffery FH, Campbell BK: In vitro development of oocytes from porcine and bovine primary follicles. Mol Cell Endocrinol 2000, 163:117-123.

93. Itoh $\mathrm{T}$, Hoshi $\mathrm{H}$ : Efficient isolation and long-term viability of bovine small preantral follicles in vitro. In Vitro Cell Dev Biol Anim 2000, 36:235-240.

94. Saha S, Shimizu M, Geshi M, Izaike Y: In vitro culture of bovine preantral follicles. Anim Reprod Sci 2000, 63:27-39.

95. Thomas FH, Leask R, Srsen V, Riley SC, Spears N, Telfer EE: Effect of ascorbic acid on health and morphology of bovine preantral follicles during longterm culture. Reproduction 2001, 122:487-495.

96. Thomas FH, Campbell BK, Armstrong DG, Telfer EE: Effects of IGFbioavailability on bovine preantral follicular development in vitro. Reproduction 2007, 133:1121-1128.

97. Khurana NK, Niemann H: Energy metabolism in preimplantation bovine embryos derived in vitro or in vivo. Biol Reprod 2000, 62:847-856.

98. Eppig JJ: Analysis of mouse oogenesis in vitro. Oocyte isolation and the utilization of exogenous energy sources by growing oocytes. J Exp Zool 1976, 198:375-382

99. Genzel Y, Ritter JB, Konig S, Alt R, Reichl U: Substitution of glutamine by pyruvate to reduce ammonia formation and growth inhibition of mammalian cells. Biotechnol Prog 2005, 21:58-69.

100. Downs SM, Coleman DL, Ward-Bailey PF, Eppig JJ: Hypoxanthine is the principal inhibitor of murine oocyte maturation in a low molecular weight fraction of porcine follicular fluid. Proc Natl Acad Sci U S A 1985, 82:454-458.
101. Buccione R, Schroeder AC, Eppig JJ: Interactions between somatic cells and germ cells throughout mammalian oogenesis. Biol Reprod 1990 43:543-547

102. Luck MR, Jeyaseelan I, Scholes RA: Ascorbic acid and fertility. Biol Reprod 1995, 52:262-266.

103. Kramer MM, Harman MT, Brill AK: Disturbances of reproduction and ovarian changes in the guinea-pig in relation to vitamin $C$ deficiency. Am J Physiol Endocrinol Metab 1933, 106:611-622.

104. Hoch-Ligeti C, Bourne GH: Changes in the concentration and histological distribution of ascorbic acid in ovaries, adrenals and livers of rats during oestrous cycles. Br J Pathol 1948, 29:400-407.

105. Deane HW: Histochemical observations on the ovary and oviduct of the albino rat during the estrous cycle. Am J Anat 1952, 91:363-413.

106. Andrade ER, van den Hurk R, Lisboa LA, Hertel MF, Melo-Sterza FA, Moreno K, Bracarense AP, Landim-Alvarenga FC, Seneda MM, Alfieri AA: Effects of ascorbic acid on in vitro culture of bovine preantral follicles. Zygote 2012, 20:379-388.

107. Buratini J Jr, Glapinski VF, Giometti IC, Teixeira AB, Costa IB, Avellar MC, Barros CM, Price CA: Expression of fibroblast growth factor- 8 and its cognate receptors, fibroblast growth factor receptor (FGFR)-3c and-4, in fetal bovine preantral follicles. Mol Reprod Dev 2005, 70:255-261.

108. Buratini J Jr, Pinto MG, Castilho AC, Amorim RL, Giometti IC, Portela VM, Nicola ES, Price CA: Expression and function of fibroblast growth factor 10 and its receptor, fibroblast growth factor receptor $2 B$, in bovine follicles. Biol Reprod 2007, 77:743-750.

109. Bodensteiner KJ, Clay CM, Moeller CL, Sawyer HR: Molecular cloning of the ovine Growth/Differentiation factor-9 gene and expression of growth/ differentiation factor-9 in ovine and bovine ovaries. Biol Reprod 1999, 60:381-386

110. Wandji SA, Pelletier G, Sirard MA: Ontogeny and cellular localization of 125I-labeled insulin-like growth factor-l, 125I-labeled follicle-stimulating hormone, and 125I-labeled human chorionic gonadotropin binding sites in ovaries from bovine fetuses and neonatal calves. Biol Reprod 1992, 47:814-822.

111. Armstrong DG, Gutierrez CG, Baxter G, Glazyrin AL, Mann GE, Woad KJ, Hogg CO, Webb R: Expression of mRNA encoding IGF-I, IGF-II and type 1 IGF receptor in bovine ovarian follicles. J Endocrinol 2000, 165:101-113.

112. Armstrong DG, Baxter G, Hogg CO, Woad KJ: Insulin-like growth factor (IGF) system in the oocyte and somatic cells of bovine preantral follicles. Reproduction 2002, 123:789-797.

113. Schams D, Berisha B, Kosmann M, Einspanier R, Amselgruber WM: Possible role of growth hormone, IGFs, and IGF-binding proteins in the regulation of ovarian function in large farm animals. Domest Anim Endocrinol 1999, 17:279-285

114. Walters KA, Binnie JP, Campbell BK, Armstrong DG, Telfer EE: The effects of IGF-I on bovine follicle development and IGFBP-2 expression are dose and stage dependent. Reproduction 2006, 131:515-523.

115. Neufeld G, Ferrara N, Schweigerer L, Mitchell R, Gospodarowicz D: Bovine granulosa cells produce basic fibroblast growth factor. Endocrinology 1987, 121:597-603.

116. Araujo VR, Duarte $A B$, Bruno JB, Pinho Lopes $C A$, de Figueiredo JR: Importance of vascular endothelial growth factor (VEGF) in ovarian physiology of mammals. Zygote 2013, 21:295-304.

117. Barboni B, Turriani M, Galeati G, Spinaci M, Bacci ML, Forni M, Mattioli M: Vascular endothelial growth factor production in growing pig antral follicles. Biol Reprod 2000, 63:858-864.

118. Ferrari B, Pezzuto A, Barusi L, Coppola F: Follicular fluid vascular endothelial growth factor concentrations are increased during $\mathrm{GnRH}$ antagonist/FSH ovarian stimulation cycles. Eur J Obstet Gynecol Reprod Biol 2006, 124:70-76.

119. Bruno JB, Celestino JJ, Lima-Verde IB, Lima LF, Matos MH, Araujo VR, Saraiva MV, Martins FS, Name KP, Campello CC, Bao SN, Silva JR, Figueiredo JR: Expression of vascular endothelial growth factor (VEGF) receptor in goat ovaries and improvement of in vitro caprine preantral follicle survival and growth with VEGF. Reprod Fertil Dev 2009, 21:679-687.

120. Hulshof SC, Fiqueiredo JR, Beckers JF, Bevers MM, Vanderstichele $H$, van den Hurk R: Bovine preantral follicles and activin: immunohistochemistry for activin and activin receptor and the effect of bovine activin $A$ in vitro. Theriogenology 1997, 48:133-142.

121. Fortune JE, Cushman RA, Wahl CM, Kito S: The primordial to primary follicle transition. Mol Cell Endocrinol 2000, 163:53-60. 
122. Knight $\mathrm{PG}$, Glister $\mathrm{C}$ : Potential local regulatory functions of inhibins, activins and follistatin in the ovary. Reproduction 2001, 121:503-512.

123. Ethier JF, Findlay JK: Roles of activin and its signal transduction mechanisms in reproductive tissues. Reproduction 2001, 121:667-675.

124. Findlay JK, Drummond AE, Dyson ML, Baillie AJ, Robertson DM, Ethier JF: Recruitment and development of the follicle; the roles of the transforming growth factor-beta superfamily. Mol Cell Endocrinol 2002, 191:35-43.

125. Liu X, Andoh K, Abe Y, Kobayashi J, Yamada K, Mizunuma H, Ibuki Y: A comparative study on transforming growth factor-beta and activin $A$ for preantral follicles from adult, immature, and diethylstilbestrol-primed immature mice. Endocrinology 1999, 140:2480-2485.

126. Xu J, Bernuci MP, Lawson MS, Yeoman RR, Fisher TE, Zelinski MB, Stouffer RL: Survival, growth, and maturation of secondary follicles from prepubertal, young, and older adult rhesus monkeys during encapsulated three-dimensional culture: effects of gonadotropins and insulin. Reproduction 2010, 140:685-697.

127. Shimizu T, Murayama C, Sudo N, Kawashima C, Tetsuka M, Miyamoto A: Involvement of insulin and growth hormone (GH) during follicular development in the bovine ovary. Anim Reprod Sci 2008, 106:143-152.

128. Kolle S, Sinowatz F, Boie G, Lincoln D: Developmental changes in the expression of the growth hormone receptor messenger ribonucleic acid and protein in the bovine ovary. Biol Reprod 1998, 59:836-842.

129. Lucy MC, Byatt JC, Curran TL, Curran DF, Collier RJ: Placental lactogen and somatotropin: hormone binding to the corpus luteum and effects on the growth and functions of the ovary in heifers. Biol Reprod 1994, 50:1136-1144.

130. Langhout DJ, Spicer LJ, Geisert RD: Development of a culture system for bovine granulosa cells: effects of growth hormone, estradiol, and gonadotropins on cell proliferation, steroidogenesis, and protein synthesis. J Anim Sci 1991, 69:3321-3334.

131. Bossaert P, De Cock H, Leroy JL, De Campeneere S, Bols PE, Filliers M, Opsomer G: Immunohistochemical visualization of insulin receptors in formalin-fixed bovine ovaries post mortem and in granulosa cells collected in vivo. Theriogenology 2010, 73:1210-1219.

132. Louhio H, Hovatta O, Sjoberg J, Tuuri T: The effects of insulin, and insulin-like growth factors I and II on human ovarian follicles in long-term culture. Mol Hum Reprod 2000, 6:694-698.

133. Simpson RB, Chase CC Jr, Spicer LJ, Vernon RK, Hammond AC, Rae DO Effect of exogenous insulin on plasma and follicular insulin-like growth factor I, insulin-like growth factor binding protein activity, follicular oestradiol and progesterone, and follicular growth in superovulated Angus and Brahman cows. J Reprod Fertil 1994, 102:483-492.

134. Gutierrez CG, Oldham J, Bramley TA, Gong JG, Campbell BK, Webb R: The recruitment of ovarian follicles is enhanced by increased dietary intake in heifers. J Anim Sci 1997, 75:1876-1884.

135. Hulshof SC, Figueiredo JR, Beckers JF, Bevers MM, van der Donk JA, van den Hurk R: Effects of fetal bovine serum, FSH and 17beta-estradiol on the culture of bovine preantral follicles. Theriogenology 1995, 44:217-226.

136. Cushman RA, DeSouza JC, Hedgpeth VS, Britt JH: Alteration of activation, growth, and atresia of bovine preantral follicles by long-term treatment of cows with estradiol and recombinant bovine somatotropin. Biol Reprod 2001, 65:581-586.

137. Murray AA, Gosden RG, Allison V, Spears N: Effect of androgens on the development of mouse follicles growing in vitro. J Reprod Fertil 1998, 113:27-33.

doi:10.1186/1477-7827-12-78

Cite this article as: Araújo et al:: In vitro culture of bovine preantral follicles: a review. Reproductive Biology and Endocrinology 2014 12:78.

\section{Submit your next manuscript to BioMed Central and take full advantage of:}

- Convenient online submission

- Thorough peer review

- No space constraints or color figure charges

- Immediate publication on acceptance

- Inclusion in PubMed, CAS, Scopus and Google Scholar

- Research which is freely available for redistribution

Submit your manuscript at www.biomedcentral.com/submit
Ciomed Central 